\title{
Monoicado: A Modification of the Monopoly Game for Science Learning for Light and Optical Instruments
}

\section{${ }^{1}$ Ayu Try Damayanti, ${ }^{2}$ Dinar Maftukh Fajar, ${ }^{3}$ Muhammad Habibbulloh}

1,2 Program Studi Tadris Ilmu Pengetahuan Alam, Fakultas Tarbiyah dan Ilmu Keguruan, Universitas Islam Negeri (UIN) KH Achmad Siddiq Jember

${ }^{3}$ Program Studi Pendidikan Ilmu Pengetahuan Alam, Fakultas Keguruan dan Ilmu Pendidikan, Universitas Islam Lamongan Universitas Islam Lamongan

Email Correspondence: dinarfisika@gmail.com

\author{
Article Info \\ Article History \\ Received:25 August 2021 \\ Revised: 07 September \\ 2021 \\ Published: 25 September \\ 2021 \\ Keywords \\ educational game, \\ instructional media, \\ monopoly, light and \\ optical instrument.
}

\begin{abstract}
Monoicado (The Science Monopoly Game on Light and Optical Instruments) is an educational game based on a monopoly game developed with the aim of helping students understand the material, encouraging students to be more active, and providing a fun atmosphere in learning science subjectson the material of Light and Optical Instruments at the junior high school level. This paper aims to describe (1) the feasibility and (2) students' responses to the results of the media development. This study implemented the $4 D$ research and development model proposed by Thiagarajan (define, design, develop, and disseminate) where the dissemination stage was not carried out. The research subjects involved 2 material experts, 2 media experts, 2 teachers as users, and 33 students from one junior high school in Bondowoso district, East Java. The data obtained were analyzed quantitatively and qualitatively. Quantitative analysis was carried out on the acquisition of validation scores given by experts, users, and students. Qualitative analysis was conducted on all responses to the media. The media developed is considered very valid in all three aspects of assessment (material, media, and practicality). Students' responses to the media are visualized in a wordcloud with the most comments: easy to understand, fun, and to train memory on the Light and Optical Instruments material.
\end{abstract}

(C) 2021 Science Education Study Program FKIP Unisla Lamongan. Monopoly Game for Science Learning for Light and Optical Instruments. Science Education and Application Journal, 3 (2), 89-101.

\section{INTRODUCTION}

Learning Natural Sciences in schools focuses on mastering the skills of opinion, studying, curiosity and their application (Permendikbud, 2013). Science learning taught in schools is expected to facilitate students to understand themselves and their environment and be able to practice their knowledge in daily activities (Ikhwati, 2014). The rules regarding learning Natural Sciences in the 2013 curriculum at Junior High Schools/Madrasah Tsanawiyah have been set by the Minister of Education and Culture (Permendikbud). The regulation confirms that Natural Sciences are designated as general sciences that must be taken by students at the SMP/MTs level (Permendikbud, 2014). Science learning at the SMP/MTs level is taught in an integrated manner by combining and integrating the sciences of biology, physics, and chemistry in a single unit so that it is referred to as integrated science.

Physics is a branch of science that observes natural phenomena in a coherent manner, where in the learning process the learners will acquire knowledge in the form of facts, 
principles and concepts and even a process of discovery (Azizah et al., 2014). Learning physics is often known to be relatively difficult when compared to learning biology and chemistry so that physics is less attractive to students. This is reported from the author's preliminary study at MTsN 2 Bondowoso, East Java.

Arifin et al, (2016) in their research found several facts about physics learning including: (1) according to students physics is a difficult subject, (2) about $70 \%$ of students do not like physics subjects and (3) the strategies used in delivering the material are less effective. Puri et al, (2016) revealed that one of the problems in the physics learning process is a strategy that is not relevant to the material. Habibbulloh (2019) also revealed that abstract physics material is one of the factors that makes students have difficulty in understanding physics concepts. Based on the results of interviews with several students, information was obtained that learning physics is the most difficult learning. According to them, it happened because of the many memorization of physics concepts and the many mathematical formulas. The researcher also conducted interviews with class VIII-D students of MTsN 2 Bondowoso during the preliminary study, learning physics was felt to be relatively difficult because physics is more dominantly known as arithmetic, there are many mathematical equations that must be studied, and are considered difficult to solve. To overcome problems in the learning process, teachers must prioritize active student involvement in the learning process which will direct the formation of their own knowledge (Siregar, 2019). Therefore, new innovations are needed to deliver subject matter and improve the quality of learning (Mayangsari, 2020). An alternative that can be used is by utilizing learning media that can stimulate students to be active, enthusiastic in learning so that it will lead to high learning motivation.

Learning media is a means, steps, methods used as learning resources. Its application serves to facilitate in conveying the subject matter. Learning media are similar to teaching aids and can be used both inside and outside the classroom. The use of media in learning can generate enthusiasm for student learning, facilitate the delivery of material to students, create effective teaching situations, provide the same encouragement and lead to the same perception (Sumiharsono, 2017). From the description above, considering the large role of the media on the success of learning, the use of learning media should be optimized properly in MTs/SMP schools.

Determination of learning media to be developed is adjusted to the characteristics of students' learning styles, both auditory, visual and or kinesthetic. Learning style is a very important learning modality. The results of observations made by researchers stated that students of class VIII-D tend to have a kinesthetic learning style. Students prefer experiments, like to move around doing things in class, this is because someone who has kinesthetic learning characteristics prefers to be directly involved in learning (Sari, 2014).

Educational game is a game which contains educational and fun elements (Cooney, 2020). Educational media applied in learning has benefits including stimulating communication skills, thinking, and being correlated with the environment (Ruipérez-Valiente et al, 2021). In addition, educational games also serve to strengthen the student body and develop his personality (Samuel et al, 2021). The application of educational games in learning can make students feel motivated and happy during learning (Rohwati, 2012). Through game learning media, it is hoped that learning can be student-centered so that it can increase interest, motivation, and learning quality.

Based on above explanation, the researchers were motivated to carry out a development of learning media, namely the monopoly game media. As is well known, monopoly is a game with the aim of controlling (monopoly) all the squares on the board through buying, renting and exchanging properties in a simplified economic system. Each player rolls the dice in turn to move his pawns, and if he lands on a square that is not owned by another player, he can buy the square at a set price. If the square has been purchased by another player, he must pay the player's rent which has also been determined (Novalita dkk., 
2014). Monopoly equipment in the form of squares, toy money, and cards will be modified according to the content of the learning material.

This monopoly learning media was chosen compared to other media because it has several advantages, including: monopoly game is familiar among children so it is not difficult to integrate learning materials into it (Rosdiana et al., 2017); as a game, monopoly supports healthy competition because every player has an equal chance to win and prosper; Monopoly game content can be repeated so as to strengthen memory (Yunarti et al., 2019); monopoly games keep all players actively involved; the monopoly game trains self-confidence (Indriani et al., 2019); Monopoly games facilitate all three learning styles (visual, auditory, and kinesthetic) (Agustin, 2014); monopoly games improve communication (AYUN \& PRASETYA, 2020; Safitri, 2019) and negotiation skills (Yasumura et al., 2001); monopoly games train the ability to take advantage of opportunities and dare to take risks (Gazdula \& Farr, 2020); and monopoly games increase interest and motivation to learn (Chusniyah, et al, 2016; Suprapto, 2013). Based on interviews, the science teacher at MTSN 2 Bondowoso strongly supports the development of game learning media because it can stimulate students to be more active in learning.

Monopoly Science for Light and Optical Instruments (abbreviated as Monoicado) is a learning media in the form of a monopoly game with the principle of learning while playing. Monoicado media is expected to facilitate the delivery of learning materials to students, as well as to create a fun learning atmosphere so that students are eager to learn and can improve student communication. The choice of material on Light and Optical Instruments at Monoicado is due to the consideration that this material has a relatively wide scope, in terms of knowledge in the form of concepts, calculations, and applications that often make students forget or experience errors during exams.

The results of research using monopoly learning media have been reported by several researchers in Indonesia. One of them is Vikagustantin, et al (2014) who documented that the game of monopoly was easy to play and liked by children. In addition, monopoly games can train students' memory to master material concepts and to train students to dare to express their opinions. The results of the research that have been carried out prove that the monopoly game learning media is feasible to be used as a learning medium. The same thing was also expressed by Ramadhani, et al (2016) who have developed the MOSIK learning media (Monopoly Physics Fun). The use of these media can stimulate student learning activities. Lailiyah, et al (2021) also developed Science Monopoly as a learning medium for solar system material and was declared valid. Likewise, Chusniyah, et al (2016) who reported that the monopoly game media was effectively used as a learning medium and could foster student interest in learning and make learning fun.

Based on the previous research, the researcher will report the results of the development of learning media by modifying the monopoly game for science learning for Light and Optical Instruments. Compared to previous studies, in addition to differences in material terms, the Monoicado media developed in this study also has novelties in terms of design (wider size is $2 \times 2 \mathrm{~m}$ ), how to play (used in 1 large class) and completeness of features (there are cards profit and loss / Kartu Untung Rugi). This learning media is intended to help science learning at KD 3.12. Analyzing the properties of light, the formation of shadows on flat and curved planes and their application to explain the process of human vision, insect eyes, and the working principle of optical instruments. The characteristics of the content on the material include factual, conceptual, and principles/laws.

\section{METHODS}

The study that has been reported in this paper is a research and development $(\mathrm{RnD})$ which aims to produce a monopoly game media for learning science on Light and Optical instruments for class VIII whose validity and attractiveness have been tested. The researcher 
runs the 4D development model proposed by Thiagarajan (1974) which consists of four stages, namely: define, design, develop, and disseminate where the disseminate stage is not carried out due to time and cost constraints.

At the Define stage, the researcher conducted a needs analysis which was broken down into preliminary analysis, student analysis, and analysis of learning objectives. At the Design stage, the researcher made a monopoly game media for science learning for Light and Optical Instruments. At the development stage, the media that has been produced is given an assessment by science teacher experts, and students.

The developed product was assessed by several experts, including 2 material experts (1 physics lecturer from Science Education Study Program, UIN KH Achmad Siddiq Jember and 1 physics lecturer from Science Education Study Program, Universitas Islam Lamongan), 2 media experts (2 learning media lecturers from Science Education Study Program, UIN KH Achmad Siddiq Jember), and 2 science teachers from MTsN 2 Bondowoso as users. In addition, this study also explores student responses, namely 33 grade VIII students at MTsN 2 Bondowoso, East Java. As a religion-based school whose classes are grouped by gender, the students who became respondents in this study were female and aged 13-14 years.

The assessment instrument is a questionnaire sheet given to validators and students. Scores are given based on a Likert scale of 1-5: SB/very good (5), B/good (4), C/fair (3), $\mathrm{K} /$ poor (2), and SK/very poor (1). Assessors can also provide qualitative comments on the questionnaire. The instrument indicators of material validation, media validation, user validation, and student responses are shown in Table 1, Table 2, Table 3, and Table 4, which are modified from (Islamiyah, 2017).

Table 1. Material validation instrument indicators

\begin{tabular}{clc}
\hline Aspects of assessment & \multicolumn{1}{c}{ Indicators } & $\begin{array}{c}\text { Number of } \\
\text { items }\end{array}$ \\
\hline $\begin{array}{l}\text { Content } \\
\text { eligibility }\end{array}$ & $\begin{array}{l}\text { The truth of the substance of the material, benefits } \\
\text { for adding insight, relevance to student needs, } \\
\text { conformity to objectives, relevance (illustration of } \\
\text { pictures, assignments) }\end{array}$ & 9 \\
- $\begin{array}{l}\text { Language } \\
\text { eligibility }\end{array}$ & $\begin{array}{l}\text { Readability, clarity of information, conformity with } \\
\text { language rules }\end{array}$ & 3 \\
- $\begin{array}{l}\text { Serving } \\
\text { eligibility }\end{array}$ & $\begin{array}{l}\text { Communicative, complete information, } \\
\text { motivational, interesting }\end{array}$ & 3 \\
\hline
\end{tabular}

Table 2. Media validation instrument indicators

\begin{tabular}{|c|c|c|}
\hline Aspects of assessment & Indicators & $\begin{array}{l}\text { Number of } \\
\text { items }\end{array}$ \\
\hline $\begin{array}{ll}- & \text { Design } \\
& \text { feasibility }\end{array}$ & $\begin{array}{l}\text { Color composition, lay-out, synchronization } \\
\text { between graphic illustrations and visual and verbal, } \\
\text { attractiveness }\end{array}$ & 7 \\
\hline $\begin{array}{l}\text { Eligibility } \\
\text { ease of use }\end{array}$ & Completeness of features, systematic presentation & 4 \\
\hline $\begin{array}{l}\text { Eligibility } \\
\text { Benefit }\end{array}$ & Applicable, makes learning easy & 2 \\
\hline $\begin{array}{ll}\text { - } & \text { Graphic } \\
\text { Eligibility }\end{array}$ & Fonts, illustrations, colors & 3 \\
\hline
\end{tabular}


Table 3. User validation instrument indicators

\begin{tabular}{clc}
\hline Aspects of assessment & \multicolumn{1}{c}{ Indicators } & $\begin{array}{c}\text { Number of } \\
\text { items }\end{array}$ \\
\hline - $\begin{array}{l}\text { Content } \\
\text { eligibility }\end{array}$ & $\begin{array}{l}\text { Clarity of purpose, suitability of the material with } \\
\text { the purpose, benefits for adding insight, relevance to } \\
\text { student needs }\end{array}$ & 5 \\
- $\begin{array}{l}\text { Linguistic } \\
\text { eligibility }\end{array}$ & $\begin{array}{l}\text { Clarity of sentences, use of communicative language } \\
\text { - } \begin{array}{l}\text { Eligibility of } \\
\text { benefit } \\
\text { Graphic } \\
\text { eligibility }\end{array}\end{array}$ & $\begin{array}{l}\text { Has an appeal, makes learning easier, contains } \\
\text { motivation, is applicable }\end{array}$ \\
$\begin{array}{l}\text { Font selection, design aesthetics and layout, image } \\
\text { and illustration quality }\end{array}$ & 3 \\
\hline
\end{tabular}

Table 4. Student responses instrument indicators

\begin{tabular}{|c|c|c|}
\hline Aspects of assessment & Indicators & $\begin{array}{c}\text { Number of } \\
\text { items }\end{array}$ \\
\hline $\begin{array}{ll}\text { - } & \text { Content } \\
\text { eligibility }\end{array}$ & $\begin{array}{l}\text { Clarity of purpose, suitability of the material with } \\
\text { the purpose, benefits for adding insight, relevance to } \\
\text { student needs }\end{array}$ & 4 \\
\hline $\begin{array}{l}\text { - Linguistic } \\
\text { eligibility }\end{array}$ & Choice of terms, use of communicative language & 2 \\
\hline $\begin{array}{l}\text { - Eligibility of } \\
\text { benefit }\end{array}$ & $\begin{array}{l}\text { Has an appeal, makes learning easier, contains } \\
\text { motivation, is applicable }\end{array}$ & 6 \\
\hline $\begin{array}{l}\text { - Graphic } \\
\text { eligibility }\end{array}$ & Font selection, image quality and illustrations & 2 \\
\hline
\end{tabular}

Data analysis was carried out quantitatively and qualitatively. Quantitative analysis is used to determine the score of the assessment results. The formula used is written in Equation (1) for the validator and Equation (2) for student responses referring to Sukardjo (2012) and Akbar (2017) with the category of assessment scores described in Tables 5 and 6. Qualitative analysis is used to examine comments, suggestions, and criticism from validators and students. The following is a description of the data analysis techniques:

$$
P=\frac{X \mathrm{i}}{X} \times 100 \%
$$

Table 5. Criteria for validator assessment scores

\begin{tabular}{ll}
\hline \multicolumn{1}{c}{ Validity Criteria } & \multicolumn{1}{c}{ Validity Level } \\
\hline $84,2-100 \%$ & Very valid or can be used without revision \\
$68,2-84 \%$ & Valid or usable but need a little revision \\
$52,2 \%-68 \%$ & Not valid, it is recommended not to use it because it needs a major \\
& revision \\
$36,2-52,2 \%$ & Invalid or cannot be used \\
$0-36,2 \%$ & Very invalid or should not be used \\
\hline
\end{tabular}

$$
\mathrm{V}_{\mathrm{ah}}=\frac{\mathrm{TSe}}{\mathrm{TSh}} \times 100 \%
$$

Table 6. Criteria for student response assessment scores

\begin{tabular}{lc}
\hline Criteria & Attractiveness Level \\
\hline $81 \%-100 \%$ & Very interesting \\
$61 \%-80 \%$ & Interesting \\
$41 \%-60 \%$ & Quite interesting
\end{tabular}




\begin{tabular}{lc}
\hline Criteria & Attractiveness Level \\
\hline $21 \%-40 \%$ & Not attractive \\
$0 \%-20 \%$ & Very Unattractive \\
\hline
\end{tabular}

\section{RESULTS AND DISCUSSION}

The results of the development of the monopoly game media for learning science on light and optical instruments are described as follows:

\section{Define}

The definition stage describes the analysis of the needs for developing monopoly game media which is detailed through preliminary analysis, student analysis, and analysis of learning objectives.

a. Preliminary analysis.

The researcher determined the main problems in science learning by conducting interviews with five science teachers at MTsN Bondowoso 2 to obtain information about the problems in science learning experienced by students. Based on interviews conducted at Madrasah Tsanawiyah Negeri (MTsN) 2 Bondowoso with science teachers in class VIII-D. When delivering lessons, teachers no longer use the lecture method. What teachers often do in learning is by showing videos, then students are given the opportunity to respond and ask questions so that learning is not centered on the teacher. But in reality not many students are active and can express their opinions. Students have difficulty in learning, especially in science lessons on Light and Optical Instruments because of the lack of learning media that can be used.

b. Student analysis.

The researcher distributed questionnaires to 33 students of class VIII-D. Students stated that the material for Light and Optical Instruments is a science material that is difficult to understand because of the many concepts and calculations. Students tend to be passive in class when learning takes place. The results of the questionnaire showed that $85.7 \%$ of students stated that they were not confident when speaking in front of the class. This is caused by several factors, including students who feel nervous, feel embarrassed, and feel afraid. Therefore, the development of learning media is needed, so that students can play an active role and learning can be more fun and not boring. Game media can be used as learning media so that students can learn without feeling pressure.

c. Analysis of Learning Objectives.

Based on the KI and KD IPA SMP number 3.12, the details of the learning indicators are as follows. (1) Describe the properties of light; (2) Identify the process of image formation in plane mirrors, convex mirrors, and concave mirrors; (3) Identify the process of image formation on a convex lens and a concave lens; (4) Explain the importance of light in the process of human vision; (5) Identify the process of image formation in the human eye; (6) Identify the parts of the eye; (7) Explain the various disorders of the eye; (8) Describe the working principle of optical instruments.

\section{Design}

The design stage is the stage of making monopoly game media based on the data obtained in the definition stage. The dimension and features are described in Table 7. Instructions for Monoicado that must be known to play are:

a. Students in the class will be divided into several groups with 5-6 members each. Each member of the group will be the leader of the game in each round of the game made to run the game piece.

b. One student was appointed as a tutor who served as a point divider, brought question cards, profit and loss cards, a monopoly game manual, and monitored the game. The 
tutor is also tasked with checking the answers of each group when they get a question card, namely a question card and a profit and loss card. The tutor determines the right or wrong answer by checking the answer key contained in the Monoicado manual.

c. Each group gets an initial capital of 200 points from the tutor. With the division of points 100 points (1), 50 points (1), 20 points (1), 10 points (1), 5 points (2), 2 points (3), 1 point (4). Each player will get 20 points from the tutor when passing the "Start" square.

d. The game starts from the "Start" square, the round of the game goes clockwise.

e. Every player who stops at the question square (Kotak Pertanyaan) has the right to buy or not to buy the question box. Players who want to buy a question box must take a question card according to the code of the plot. Players who cannot answer the question are not entitled to purchase the question square. Players who can answer questions have the right to buy question boxes and must pay the tutor according to the price listed on the plot. Next, the player will get a question card.

f. Players who stop at another player's question square must take a profit and loss card (KARTU UNTUNG RUGI) from the tutor containing questions about that square. If profitable (can answer questions) then the players don't have to pay rent to the owner of the asset. If players lose (can't answer the question) then they have to pay the rental price to the owner of the asset.

g. Players who stop at the opportunity square (Kotak Kesempatan) must take a chance card and carry out the contents of the card.

h. Players who stop at the general fund square (Kotak Dana Umum) must take a general fund card and carry out the contents of the card.

i. Players who stop at the smart square (Kotak SMART) must take a smart card and read out the contents of the card.

j. The winner in the game is determined from the highest number of points obtained by each group.

Monopoly Science of Light and Optical Instruments (Monoicado) can be used after students gain initial knowledge about the material. The implementation of learning using Monoicado media can be done 3 times face to face within 45 minutes, at the end of the game the teacher will evaluate the learning outcomes in each meeting, discuss problems that cannot be solved by students and conduct discussions before learning ends. 


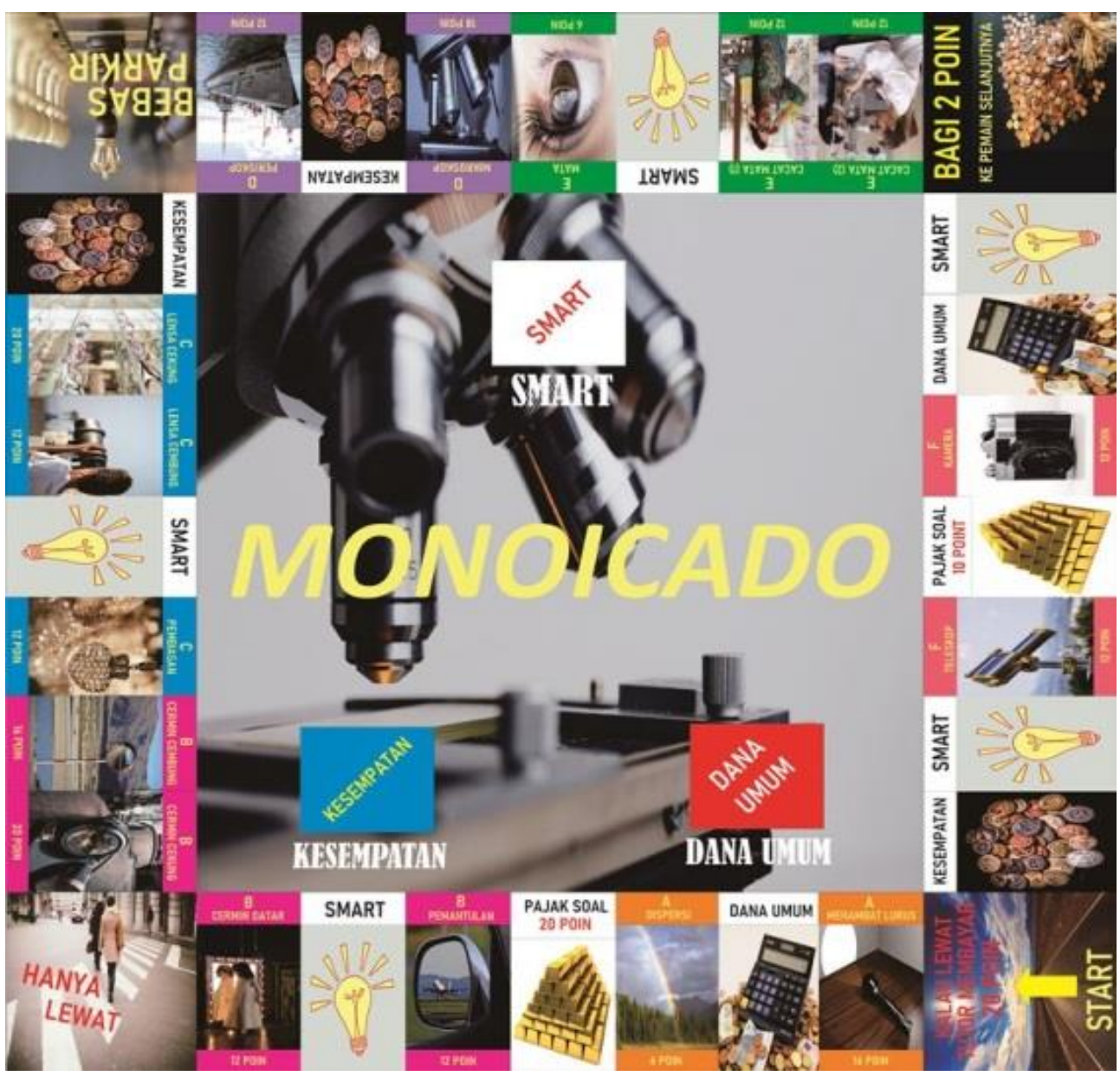

Figure 1. Monoicado Board

The media equipment for the game monopoly on Light and Optical Instruments is as follows:

Table 7. Monoicado equipment

\begin{tabular}{|c|c|c|c|}
\hline \# & Equipment & Description & Image \\
\hline 1 & Board & $\begin{array}{l}\text { Printed in size }(2 \times 2 \mathrm{~m}) \text {. A total of } 32 \text { plots } \\
\text { consisting of } 1 \text { start plot, } 16 \text { cards for Light } \\
\text { and Optical Instruments, } 2 \text { general fund plots, } \\
2 \text { tax questions, } 3 \text { opportunity plots, } 1 \text { pass } \\
\text { only plot, } 5 \text { smart plots, } 1 \text { free parking plot, } 1 \\
\text { plot. for points. }\end{array}$ & \\
\hline 2 & Dice & Use 2 dice & \\
\hline 3 & Game Pawns & $\begin{array}{l}\text { Uses } 6 \text { pawns as markers that represent the } \\
\text { player. }\end{array}$ & \\
\hline 4 & Question Cards & $\begin{array}{l}\text { A total of } 16 \text { cards containing a description of } \\
\text { the subject matter of Light and Optical } \\
\text { Instruments that have been validated. }\end{array}$ & \\
\hline
\end{tabular}




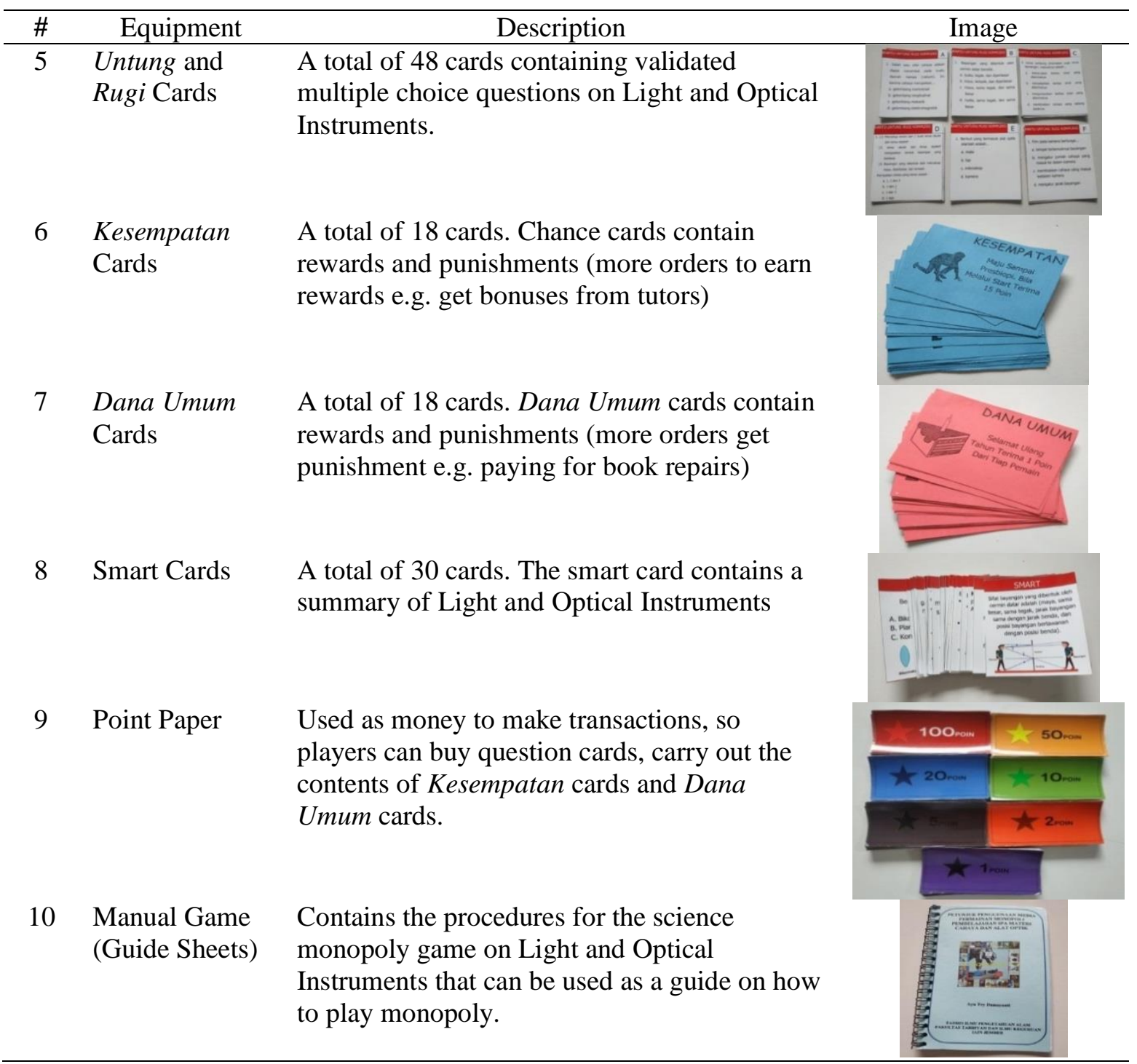

\section{Develop}

The development stage is the stage to assess the validity of the monopoly game media according to expert judgments (material experts, media experts, and users) and the attractiveness of the monopoly game media according to student responses. The results of the assessment as recapitulated in Table 8 are calculated using Equation (1) and Equation (2) with the criteria in Table 5 and Table 6.

Table 8. Expert Assessment Results and Student Responses

\begin{tabular}{cccc}
\hline$\#$ & Evaluation & Score Percentage & Category \\
\hline 1 & Material Expert & $92 \%$ & Very valid \\
2 & Media Expert & $91,87 \%$ & Very valid \\
3 & User Expert & $93,84 \%$ & Very valid \\
4 & Student Response & $85,62 \%$ & Very interesting \\
\hline
\end{tabular}

The validation results from material experts, media experts, and user experts can be seen in Table 8. Based on these data, the percentage of validity is obtained (92\%); $(91.87 \%)$; and $(93.84 \%)$ so that the development of monopoly game media is included in the "Very Valid" category with some revision notes from the validators, for example: suggestions for images on the dispersion question plot and plane mirrors can be replaced with real images as needed, smart cards visualized in the form of pictures, the procedures for the game of 
monopoly are made in the form of books/brochures and added with the KI and KD of the material taken, points should be printed using thicker paper to make it more durable. These suggestions have been added to the media.

The results of the student response test on the development of Monoicado can be seen in Table 8. This data was obtained after carrying out learning 3 times with students (1 meeting for apperception, interviews, and small-scale tests to see the readability of the media and 2 meetings for large-scale tests to see the overall student responses). Based on the data obtained a percentage $(85.62 \%)$ so that the monopoly game media development is included in the "Very Interesting" category. The learning media is stated to be able to be used as a learning medium in schools. The following word cloud (Figure 2) is words often mentioned by the students in their responses:

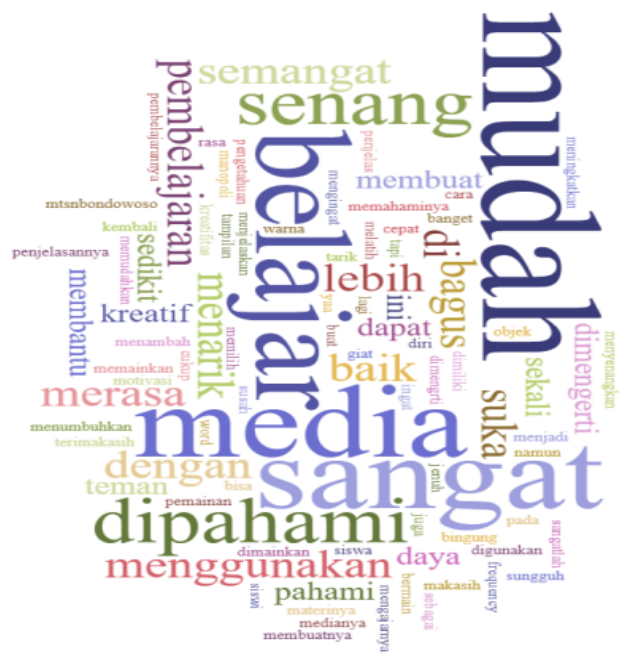

Student response grouping:

- Easy to understand comments from 16 students

- Fun comments from 11 students

- Very interesting comments from 5 students

- Excited to learn comments from 5 students

- Practicing the creativity of comments from 3 students

- Nice comments from 3 students

- Confused comment from 1 student

Figure 2. Word Cloud Student Comments against Monoicado

Criticisms and suggestions submitted by students were supported by several previous researchers in Indonesia. One of them is Vikagustanti, et al (2014) documenting that the game of monopoly is easy to play and liked by children. In addition, monopoly games can train students' memory to master material concepts and to train students to dare to express their opinions. The results of the research that have been carried out prove that the monopoly game learning media is feasible to be used as a learning medium.

The same thing was also revealed by the research of Chusniyah, et al (2016). The results reported are that the monopoly game media is effectively used as a learning medium and can foster student interest in learning and make learning fun. The use of monopoly games as a learning medium requires students to master the material in a fun way so that it can foster student interest in learning, the existence of interest makes students have high enthusiasm to find out something that makes them interested. Interest is one of the psychological aspects that can encourage someone to achieve goals. Similarly, research that has been conducted by Prasetiyawati, et al (2012) which revealed that educational play tools can increase children's creativity and intelligence.

What is unique about Monoicado compared to previous studies is that it is relatively large $(2 \times 2 \mathrm{~m})$ which can be played in groups in 1 class together. Another uniqueness that Monoicado has is the existence of a "Profit and Loss Card / Kartu Untung Rugi". With this feature, in addition to gaining knowledge from the content of the material read, players are also taught to take risks. A player who stops at another player's question square must take a profit and loss card from the tutor containing questions about that square. If he is profitable (can answer questions) then he doesn't have to pay rent to the owner of the asset. If he loses (can't answer the question) then he has to pay the rental price to the owner of the asset. 
Lailiyah, et al (2021) also reported that the science monopoly media on the Solar System material was declared valid, the validity aspect was shown from the validation results with a very valid category. The use of monopoly learning media can make it easier for students to understand the material presented. This statement is in accordance with research conducted by Susanto (2012) documenting that the monopoly game media is very feasible to use in learning, and can make it easier for students to understand the material and make learning more fun. This result is also supported by Kurniawan (2020) who states that the use of monopoly learning media is quite effective and can be one of the teacher's choices to be used as media during the teaching and learning process.

\section{CONCLUSION}

The research that has been carried out has produced a product in the form of a monopoly game media for science learning for the material of Light and Optical Instruments for class VIII. Based on the results of research and discussion, the following conclusions are obtained:

The validation results from 2 material experts on the development of monopoly game media are considered very valid $(92 \%)$. The validation results from 2 media experts were considered very valid $(91.87 \%)$. The validation results from 2 expert users are considered very valid $(93.84 \%)$ so it can be concluded that the developed monopoly game learning media can be used as a learning medium for class VIII-D MTsN 2 Bondowoso on KD 3.12 material. Analyzing the properties of light, formation of shadows on flat and curved planes and their application to explain the process of human vision, insect eyes, and the working principle of optical instruments, except for the material for the sense of sight of insects.

Based on the student response trials conducted in class VIII-D, students responded that the monopoly game media was very interesting $(85.62 \%)$ with the descriptions: easy to understand, fun, and to train memory on the material of Light and Optical Instruments.

\section{SUGGESTION}

The following are suggestions recommended by the developer: (1) learning using Monoicado media should be carried out after students receive the main learning from the teacher, (2) teachers are expected to allocate sufficient duration (about 2 hours of lessons or more) in learning using Monoicado media, and (3) teachers are expected to prepare for the risk of noise in the classroom.

\section{REFERENCES}

Agustin, V. (2014). Pengembangan Media Pembelajaran Moge (Monopoli Geografi) Untuk Meningkatkan Hasil Belajar Siswa Pada Pokok Bahasan Menganalisis Hubungan Antara Manusia Dengan Lingkungan Sebagai Akibat Dari Dinamika Atmosfer Di Kelas X MAN Mojosari. Swara Bhumi, 3(3).

Akbar, S. D. (2017). Instrumen Perangkat Pembelajaran cetakan kelima. Bandung: PT Remaja Rosdakarya.

Arifin, Zainal dkk. (2016). Pengaruh Model Quantum Learning Disertai Metode Eksperimen Terhadap Hasil Belajar Fisika Siswa di SMA Negeri Kalisat. Jurnal Pembelajaran Fisika, 4(4), 366.

Ayun, H. K., \& Prasetya, S. P. (2020). Pengembangan Media Monopoli Pada Materi "Pengelolaan Sumber Daya Alam di Indonesia" untuk Melatih Kemampuan Berkomunikasi dan Bekerjasama serta Hasil Belajar Siswa Kelas XI SMAN 1 Krembung Sidoarjo. Swara Bhumi, 2(1).

Azizah dkk. (2014). Penerapan Model Inkuiri Terbimbing untuk Meningkatkan Keterampilan Proses Sains dan Hasil Belajar Fisika Siswa Kelas X.C di MAN 2 Jember Tahun Ajaran 2013/2014. Jurnal Pendidikan Fisika, 3(3), 235. 
Chusniyah, Irfatul dkk. (2016). Keefektifan Permainan Monopoli Berbasis Science Edutainment Tema Tata Surya Terhadap Minat Belajar dan Karakter Ilmiah Siswa Kelas VIII. Unnes Science Education Journal, 5(2), 1242.

Cooney, Adeline and Darcy, Eamon. (2020). 'It was fun': Exploring the pedagogical value of collaborative educational games. Journal of University Teaching \& Learning Practice, 17(3).

Gazdula, J., \& Farr, R. (2020). Teaching risk and probability: Building the Monopoly® board game into a probability simulator. Management Teaching Review, 5(2), 133-143.

Habibbulloh, M. (2019). Effectiveness of the guided discovery model based virtual lab PhET toward mastery students'concept on topic photoelectric effect. Science Education and Application Journal, 1(1), 1-9.

Ikhwati, Hestiana. (2014). Pengembangan Media Flashcard IPA Terpadu dalam Pembelajaran Model Kooperatif Tipe Students Teams Achievement Divisions (STAD) Tema Polusi Udara. Unnes Science Education Journal, 3(2), 482.

Indriani, M. N., Isnarto, I., \& Mariani, S. (2019). The implementation of PBL (problem based learning) model assisted by monopoly game media in improving critical thinking ability and self confidence. Journal of Primary Education, 8(2), 200-208.

Islamiyah, Tsuaibatul. (2017). Pengembangan Media Pembelajaran Berbasis Permainan Monopoli Mata Pelajaran IPS Materi Proses Persiapan Kemerdekaan Indonesia Kelas VIII di MTs Nurul Ulum Malang. Skripsi, Universitas Islam Negeri Maulana Malik Ibrahim, Malang.

Kurniawan, D. A. (2020). Penggunaan media belajar monopoli untuk meningkatkan motivasi dan hasil belajar siswa. Jurnal Review Pendidikan dan Pengajaran, 3(1), 10-15..

Lailiyah, S., Kuswanti, N., \& Fitriyah, L. A. (2021). Monopoli IPA Sebagai Media Pembelajaran Di SMP/MTs Kelas VII Pada Materi Tata Surya. Ed-Humanistics: Jurnal Ilmu Pendidikan, 6(1), 779-786.

Mayangsari, D.A., Nurkanti, Mia., Kurniawan., I. S., Suganda, Handi. (2020). Meningkatkan Hasil Belajar Siswa Menggunakan Teams Games Tournament (TGT) dan Permainan Hompimpa pada Materi Sel. Science Education and Application Journal. 2 (1). 12-21.

Novalita, Y., Rahmawati, A., \& Qowi, N. H. (2014). MONAS (Monopoli Asli Indonesia) sebagai media bermain untuk membentuk karakter Anak Cinta Indonesia. Pekan Ilmiah Mahasiswa Nasional Program Kreativitas Mahasiswa-Karsa Cipta 2013.

Permendikbud Republik Indonesia (2013) Tentang Kurikulum 2013 Kompetensi Dasar Sekolah Menengah Pertama/Madrasah Tsanawiyah.

Permendikbud Republik Indonesia Nomor 58. (2014). Tentang Kurikulum 2013 Sekolah Menengah Pertama/Madrasah Tsanawiyah.

Prasetiyawati, Dwi, dkk. (2012). Upaya Identifikasi Kreativitas Kader-Kader Paud di Kecamatan Ungaran Melalui Alat Permainan Edukatif (APE). PAUDIA: Jurnal Penelitian dalam Bidang Pendidikan Anak Usia Dini, 1(1), 61.

Putri, Hendrasti Kartika dkk. (2016). Model Pembelajaran Inkuiri Terbimbing Disertai Teknik Peta Konsep Dalam Pembelajaran Fisika di SMA 1. Jurnal Pembelajaran Fisika, 4(4), 321.

Ramadhani, Nendy dkk. (2016). Pengembangan Media Educational Game 'Monopoli Fisika Asik (Mosik)' Pada Mata Pelajaran IPA di SMP. Jurnal Pembelajaran Fisika, 5(3), 243.

Rohwati, M. (2012). Penggunaan Education Game untuk Meningkatkan Hasil Belajar IPA Biologi Konsep Klasifikasi Makhluk Hidup. JPII, 1(1), 76.

Rosdiana, M., Hidayat, J. N., \& Prijambodo, R. F. N. (2017). Pengembangan Media Pembelajaran Permainan Monopoli Sains pada Siswa Kelas IV SDN Pragaan Laok I. Alpen: Jurnal Pendidikan Dasar, 1(2). 
Ruipérez-Valiente J. A., Gomez M. J., Martínez P. A. and Kim Y. J. 2021. Ideating and Developing a Visualization Dashboard to Support Teachers Using Educational Games in the Classroom, in IEEE Access, vol. 9, pp. 83467-83481, doi: 10.1109/ACCESS.2021.3086703.

Safitri, I. (2019). Keefektifan Media Pembelajaran Monosa (Monopoli Bahasa) Terhadap Keterampilan Berbicara Siswa Kelas VII SMP Negeri 1 Watansoppeng. Universitas Negeri Makassar.

Samuel Spaulding, Jocelyn Shen, Haewon Park and Cynthia Breazeal. 2021. Towards Transferrable Personalized Student Models in Educational Games. In Proc. of the 20th International Conference on Autonomous Agents and Multiagent Systems (AAMAS 2021), Online, May 3-7, 2021, IFAAMAS, 9 pages.

Sari, Ariesta Kartika. (2014). Analisis Karakteristik Gaya Belajar Vak (Visual, Auditorial, Kinestetik) Mahasiswa Pendidikan Informatika Angkatan 2014. Edutic - Scientific Journal of Informatics Education, 1(1), 3.

Siregar, Nurhasana. (2019). Peningkatan Kemampuan Pemahaman Konsep IPA Siswa dan Pengelolaan Pembelajaran Guru dengan Menerapkan Model Pembelajaran Berbasis Masalah. EKSAKTA : Jurnal Penelitian dan Pembelajaran MIPA, 4(1), 61.

Sukardjo. (2012). Evaluasi Program Pembelajaran. Yogyakarta: Pps UNY.

Sumiharsono, M Rudy dan Hasbiyatul Hasanah. (2017). Media Pembelajaran. Jember: Cv Pustaka Abadi.

Suprapto, A. N. (2013). Permainan Monopoli Sebagai Media untuk Meningkatkanminat Belajar Tata Boga Di SMA. Jurnal Ilmiah Guru Caraka Olah Pikir Edukatif, 1.

Susanto, Arif dan Muji Sri Prastiwi. (2012). Permainan Monopoli Sebagai Media Pembelajaran Sub Materi Sel Pada Siswa SMA Kelas XI IPA. Unnes Science Education Journal, 1(1), 1-6.

Thiagarajan, Sivasailam, dkk. (1974). Instructional Development for Training Teachers of Exceptional Children. Washinton DC: National Center for Improvement Educational System

Vikagustanti, Dea Aransa ddk. (2014). Pengembangan Media Pembelajaran Monopoli IPA Tema Organisasi Kehidupan Sebagai Sumber Belajar untuk Siswa SMP. Unnes Science Education Journal, 3(2), 474.

Yasumura, Y., Oguchi, K., \& Nitta, K. (2001). Negotiation strategy of agents in the Monopoly game. Proceedings 2001 IEEE International Symposium on Computational Intelligence in Robotics and Automation (Cat. No. O1EX515), 277-281.

Yunarti, S., Ansori, Y. Z., \& Saputra, D. S. (2019). Media Monopoli Menciptakan Suasana Yang Menyenangkan Pada Pembelajaran IPS. Prosiding Seminar Nasional Pendidikan, $1,764-770$. 